\title{
FACTORS ASSOCIATED TO SMOKING BEHAVIOR IN WORSHIP PLACES IN DENPASAR BALI INDONESIA
}

\author{
Ketut Suarjana ${ }^{1,2}$, Djazuly Chalidyanto ${ }^{1}$, Mochammad Bagus Qomaruddin ${ }^{1}$ and \\ Chatarina Umbul Wahyuni ${ }^{*}$ \\ ${ }^{1}$ Doctoral Program, Faculty of Public Health, Universitas Airlangga Surabaya, Indonesia \\ ${ }^{2}$ School of Public Health, Faculty of Medicine, Universitas Udayana, Bali, Indonesia
}

\begin{abstract}
Since 2013, City of Denpasar government has adopted smoke-free law regarding smokefree areas including worship places. However, compliance with smoke-free law at worship places remains low. The implementation of the law faces several obstacles particularly at Hindu temples since it is mostly semi-opened spaces and high social acceptability of smoking where cigarette and smoking have been deeply engrained within social and religious life. Hence, this study aims to assess factors that associated with smoking behavior at worship places particularly at Hindu temple in Denpasar Bali Indonesia. This study was a cross-sectional study, conducted in the city of Denpasar, involving 192 samples which selected using multistage random sampling. The data was collected using a structured questionnaire then analyzed using path analysis. There were 12 factors analyzed such as past behavior of smoking, exposure to anti-smoking policies, nicotine dependence, knowledge and attitude regarding second-hand smoke, knowledge and attitude regarding implementation of smoke-free law, sociodemographic (age, education), social norms of smoking (descriptive and injunctive). Of the 11 factors, 5 factors had a significant effect on smoking behavior. Past behavior of smoking had a direct negative effect with a standardized coefficient (beta) -0.34 ( $\mathrm{p}<0.01$ ); followed by nicotine dependence which had an indirect negative effect (beta $-0.07 ; \mathrm{p}=0.01$ ). Meanwhile, positive direct and indirect effects showed by descriptive norms (beta $0.14 ; \mathrm{p}=0.04$ ); injunctive norms (beta $0.15 ; \mathrm{p}=0.02$ ) and education (beta $0.14 ; \mathrm{p}=0.03$ ). Past behavior of smoking had the highest effect on smoking behavior in worship places. Hence, continuous education, socialization and improved supervision to the implementation of smoke-free law remain crucial. Moreover, social norm factors also need more attention, so that a culture-sensitive strategy could be considered.
\end{abstract}

Keywords: Smoking behavior, worship places, compliance, smoke-free law, Denpasar Bali

\section{Introduction}

Indonesia is home to almost one hundred million smokers, where 33.6\% of the adult population and $19.4 \%$ of young people age 13-15 years are smokers. Based on the recent Indonesian Basic Health Survey in 2018, the prevalence of smokers in Indonesia was $28.8 \%$. WHO estimates that the prevalence of smoking in Indonesia will reach $42.7 \%$ in 2020 (WHO, 2015). Indonesia is the only country in the Asia Pacific region that has yet to ratify the WHO-FCTC despite the significant tobacco burden within the country. Meanwhile, the smoking rate in Bali Province was also high at $23.5 \%$. Denpasar, the capital city of Bali which has an area of $127.78 \mathrm{~km} 2$ with a population of 930.600 inhabitants, had the highest prevalence among its districts at $27.4 \%$ (Kementerian Kesehatan Republik Indonesia, 2018).

Indonesia yet to ratified the WHO's framework convention on tobacco control (WHO-FCTC), nevertheless, there is an ongoing progress on tobacco control including adoption of smoke free law. In 2011, Bali Province was the first province to pass a comprehensive smoke-free law then followed by City of Denpasar in 2013 (Pemerintah Provinsi Bali, 2011). Denpasar's smoke-free law took effect in 2014 and banned smoking and tobacco advertising in most public places including healthcare facilities, schools, children's playgrounds, worship places, public transportation, workplaces, and public places with no exemptions or indoor designated smoking areas (Pemerintah Kota Denpasar, 2013). However, according to the recent compliance survey conducted in 2019, the overall compliance with smoke-free law in Denpasar remains low (32.9\%), below the target of compliance (80\%). By 
type of venue, only three of the venue have reached the compliance target i.e. the university/campus, school and the primary health care. While, most of them remain below the target including worship places which had $31,4 \%$ of compliance (even below the overall compliance) (Suarjana, et al, 2018).

Compliance with smoke-free law is urgently increased, since low compliance will weaken the public health benefits of the law and could even lead to negative responses from society and considered ineffective. The implementation of smoke-free law was aimed not only to protect against cigarette smoke exposure but also to emphasize the importance of environmental health because cigarette butts are one of the most common pollutants, to denormalize smoking norms in society, and to improve the quality of the society (Kennedy et al., 2012).

One of the worship places that require attention in Bali is the Hindu temple. Bali is one of the prominent tourist destinations in the world which also known as the island of thousand temples since the majority of the residents are Hindus. In contrast to other worship places which are mostly enclosed buildings, the Hindu temples are mostly opened or semi-opened spaces. Moreover, provision of cigarette becomes part of hospitality as well as tradition at almost every religious and customary event. Research shows that smoking behavior is considered normal in secular and religious life in Indonesia, where cigarettes often presented at every religious event, thus the compliance with smoke-free law remains low (Byron et al., 2015).

Numerous studies have showed that compliance to the smoke-free at public places associated with many factors either internal factors (sociodemographic characteristics, nicotine dependence, psychological status, past behavior, quit attempts, knowledge and attitude regarding smoke-free law) or external factors (monitoring and enforcement system of a smoke-free law, social norms of smoking). The perception of smoking norms in society can be explained from the Theory of Normative Social Behavior (TNSB). TNSB based on the premise that the effect of descriptive norms on individual behavior is moderated through three normative mechanisms i.e. injunctive norms, outcome expectations and group identity (Rimal \& Real, 2005).

Several studies showed social norms was a significant predictor of non-compliance behavior. In LMIC countries, the implementation of a smoke-free law at public places should be performed together with measures to change smoker's beliefs, social and cultural smoking norms (Echeverría, et al., 2013; Byron et al., 2019). Hence, assessment on factors related to compliance with the smoke-free law at public places in setting such as Indonesia should include an assessment of social norms particularly in worship places since every religious event, provision of cigarette become part of tradition. Hence, to identify specific factors either internal or external factors and create strategies accordingly, this study aims to assess factors associated with compliance with smoke-free law at worship places.

\section{Methods}

This was a cross-sectional study which located in the city of Denpasar Bali. City of Denpasar has 35 traditional villages (desa adat) and 358 sub-village (banjar) which spread across four districts i.e. 2 traditional villages in West Denpasar District, 10 traditional villages in North Denpasar District, 12 traditional villages in East Denpasar District, and 11 traditional villages in South Denpasar District. This study was conducted in November 2019 until January 2020.

The study population is smokers who belong to the traditional village in the city of Denpasar which accounted approximately 116.910 smokers (Pemerintah Kota Denpasar, 2018). The sample size was calculated using a single sample formula for correlation test (Lwanga \& Lemeshow, 1997). Based on the calculation of the formula, the minimum sample size is 113 . Moreover, the relationship between these variables will be analyzed using path analysis, hence, the calculation of the sample size could be calculated using the "rule of thumb", i.e. the estimated number of parameters is multiplied by 5 until 10. In this study, the estimated number of parameters is 34 
parameters, so that the required sample size is 170 up to 340 . Hence, based on these two sample size calculations and to facilitate sampling for each cluster, the sample size used in this study was 192 people.

The sample was selected using multistage random sampling. Firstly, 8 traditional village representing each district in the city of Denpasar were selected using simple random sampling. Then, in every selected traditional village, 2 sub-village were selected using simple random sampling (total 16 sub-village). Finally, from each of sub-village, we selected 12 samples (respondents) using simple random sampling. Smoker categorization questions were used to determine eligibility to participate in this study. Two standard questions for determining whether or not a person is considered a smoker were used to categorize potential samples (Pierce, et al., 1996). These questions were as follows: 1) "Have you smoked at least 100 cigarettes in your lifetime?"; and 2) "Have you smoked any cigarettes in the last 30 days (even a puff)?". To be eligible to participate in the study, respondents had to select yes to both items. Data was collected through interview using a structured questionnaire by six previously trained enumerators.

The factors that affected the compliance in worship places were analyzed using path analysis by STATA software. There are 13 factors examined in this study i.e., past behavior of smoking, exposure to anti-smoking policies, nicotine dependence, psychological factors (stress, anxiety), knowledge and attitude regarding second-hand smoke SHS), knowledge and attitude regarding implementation of smoke-free law (SFL), sociodemographic (age, education), social norms of smoking (descriptive and injunctive). Of the 13 factors, psychological factors (stress, anxiety) were excluded from path analysis since the descriptive result showed those factors did not vary. Ethical approval was obtained from the Research Ethics Commission of the Faculty of Medicine, Udayana University Denpasar Bali with number: 2106 / UN14.2.2.VII.14 / LP / 2019..

\section{Results}

The study succeeded in interviewing 192 respondents. Table 1 shows that among 192 respondents, most of them were adults aged 26-45 years (51.0\%). Based on sex, most of the respondents were male (98.4\%). The education level of the respondents showed that most of them passed senior high school (58.8\%). Meanwhile, the type of occupation was mostly self-employed (38.6\%).

Table 1. The characteristics of respondents based on home visit interview

\begin{tabular}{ll}
\hline Variable & $\mathrm{n}=192$ \\
\hline Age (years) mean \pm SD & $35.3 \pm 11.2$ \\
\hline Adolescent (12-25 years) & $53(27.6) *$ \\
\hline Adult (26-45 years) & $98(51.0)$ \\
\hline Elder (46-65 years) & $41(21.4)$ \\
\hline Sex & $3(1.6)$ \\
\hline Female & $189(98.4)$ \\
\hline Male & $3(1.6)$ \\
\hline Education level & $19(9.9)$ \\
\hline$<6$ th grade & $170(88.5)$ \\
\hline$<9$ th grade & $6(3.1)$ \\
\hline$>9$ th grade & $13(6.8)$ \\
\hline Occupation & $64(33.3)$ \\
\hline Unemployed & \\
\hline Government employee & \\
\hline Private employee & \\
\hline
\end{tabular}




\begin{tabular}{ll}
\hline Self employed & $74(38.6)$ \\
\hline Retired & $2(1.0)$ \\
\hline Farmer & $3(1.6)$ \\
\hline Housewife & $2(1.0)$ \\
\hline Student & $25(13.0)$ \\
\hline Others & $3(1.6)$ \\
\hline
\end{tabular}

*53 (27.6) = 53: absolute amount, (27.6): percentage

Meanwhile, Table 2 shows that of 11 factors, only 5 factors had a significant effect on compliance in worship places. The past smoking behavior of respondents in other public places has a direct negative effect on compliance with smoke-free law in worship places. The total effect of past smoking behavior inhibits compliance with a standardized coefficient of -0.344 and p-value $<0.01$.

Table 2. Result of Path Analysis of Compliance Factors in Worship Places

\begin{tabular}{|c|c|c|c|c|c|c|c|}
\hline \multirow[t]{2}{*}{$\mathrm{Nu}$. } & \multirow[t]{2}{*}{ Factors } & \multicolumn{2}{|c|}{ Direct effect } & \multicolumn{2}{|c|}{ Indirect effect } & \multicolumn{2}{|c|}{ Total effect } \\
\hline & & Coeff* & p-value & Coeff* & $\mathrm{p}$-value & Coeff* & $\mathrm{p}$-value \\
\hline 1. & $\begin{array}{l}\text { Past smoking } \\
\text { behavior }\end{array}$ & -0.344 & $\mathrm{p}<0.01$ & - & - & -0.344 & $\mathrm{p}<0.01$ \\
\hline 2. & $\begin{array}{l}\text { Exposure to anti- } \\
\text { smoking policies }\end{array}$ & - & - & -0.004 & 0.366 & -0.004 & 0.366 \\
\hline 3. & $\begin{array}{l}\text { Nicotine } \\
\text { dependence }\end{array}$ & - & - & -0.069 & 0.012 & -0.069 & 0.012 \\
\hline 4. & $\begin{array}{l}\text { Knowledge } \\
\text { regarding SHS }\end{array}$ & - & - & -0.003 & 0.841 & -0.003 & 0.841 \\
\hline 5. & $\begin{array}{l}\text { Attitude toward } \\
\text { SHS }\end{array}$ & 0.082 & 0.216 & - & - & 0.082 & 0.216 \\
\hline 6. & $\begin{array}{l}\text { Knowledge } \\
\text { regarding SFL }\end{array}$ & - & - & 0.002 & 0.741 & 0.002 & 0.741 \\
\hline 7. & $\begin{array}{l}\text { Attitude toward } \\
\text { SFL }\end{array}$ & - & - & -0.023 & 0.525 & -0.023 & 0.525 \\
\hline 8. & Age of respondent & 0.097 & 0.151 & 0.001 & 0.842 & 0.097 & 0.149 \\
\hline 9. & $\begin{array}{l}\text { Education level of } \\
\text { respondent }\end{array}$ & 0.136 & 0.035 & -0.001 & 0.965 & 0.136 & 0.035 \\
\hline 10. & $\begin{array}{l}\text { Perceived of } \\
\text { descriptive norm }\end{array}$ & 0.145 & 0.041 & -0.001 & 0.842 & 0.145 & 0.042 \\
\hline 11. & $\begin{array}{l}\text { Perceived of } \\
\text { injunctive norm }\end{array}$ & 0.147 & 0.025 & 0.005 & 0.535 & 0.152 & 0.023 \\
\hline
\end{tabular}

Coeff* $=$ Standardized Coefficient Beta; Root Mean Squared Error of Approximation = 0,077

Physical factor of the respondents, which is called nicotine dependence, had an indirect negative effect to smoking behavior in temples. The nicotine dependence inhibits compliance by strengthening the past smoking behavior in other public places which also hinders compliance in worship places. The total effect of nicotine dependence factor on compliance in worship places with a standardized coefficient of -0.692 and p-value $=0.012$. 
Meanwhile, the respondents' knowledge regarding SHS showed that the SHS knowledge factor had no effect on compliance in worship places (standardized coefficient -0.003 ; $\mathrm{p}$-value $=0.841$ ). Similar result also showed by the respondent's attitude towards SHS which had no effect on compliance in the worship places (standardized coefficient 0.082 ; $p$-value $=0.216$ ). The respondent's knowledge regarding SFL also has no effect on compliance in worship places (standardized coefficient 0.002 ; p-value $=0.741$ ). Likewise, the attitude of respondents towards SFL also had no effect on compliance in worship places (standardized coefficient -0.023 ; $\mathrm{p}$-value $=0.525$ ).

The results of the sociodemographic analysis showed that the age of the respondents had no effect on compliance in worship places (standardized coefficient 0.097; p-value $=0.149$ ). However, the education level of respondents had a direct positive on compliance in worship places. The total effect of the education level of the respondents increased compliance in worship places with a standardized coefficient of 0.136 and p-value $=0.035$.

Moreover, respondent's perception regarding the descriptive norm of smoking in society showed that the perception of the descriptive norm had a direct positive on compliance in worship places. The total effect of the perceived descriptive norms increased compliance in worship places with a standardized coefficient of 0.145 and p-value of 0.042. Meanwhile, respondents' perceptions regarding injunctive norms indicated that perceptions of injunctive norms also had a direct positive effect on compliance in worship places. The total effect of perceived injunctive norms also increased compliance in worship places with a standardized coefficient of 0.152 and p-value $=0.023$.

\section{Discussion}

In this study, to assess the factors that affect the compliance in worship places, we used almost all internal factors including: sociodemographic characteristics (age, sex, education level), physical factors (nicotine dependence), psychological factors (stress, anxiety), past smoking behavior, history of exposure to anti-smoking policies other than KTR, as well as knowledge and attitudes towards SFL and SHS. Meanwhile, the external factors assessed were the social norms of smoking. The other external factors such as the supervision and enforcement system were excluded since the worship places had never been enforced by smoke-free law, hence it could not be assessed. In contrast to several other studies that only use combined social norms as predictors of smoking behavior, this study divided the social norm into two different variables i.e., perceived descriptive norms and perceived injunctive norms.

The results showed that the past smoking behavior has a direct negative effect on compliance in worship places. This result indicates that the more frequent smokers have the habit of smoking in public places or other places regulated in the SFL, the lower the compliance in worship places. This result consistent with other study which also found that smokers who have past smoking behavior in public places could be categorized as smoker with a bad attitude which is resistant to anything that interferes their smoking activity, including the existence of a smokefree policy (Kegler et al., 2014). Smoking habits and bad attitudes towards the healthy environment will be carried over to other public places even to public places that are normatively inappropriate or unethical to smoke, such as in health care facilities (Tadesse \& Zawdie, 2019), as well as in worship places which shown in our study. In our study, we found that almost all respondents had smoked before in other public places beside in worship places. Many studies across the world also show that smoking behavior in public places is mostly found in hospitality sectors such as hotels, bars, restaurants and cafes (Reis et al., 2014). Based on these findings, to improve compliance in worship places, smoking behavior and compliance in other public places, particularly in hospitality sectors, must be properly supervised and enforced. One of the most effective strategies was to establish an internal monitoring system in each place of those sectors in order to continuously conduct education, socialization, supervision and enforcement (Devhy, et al., 2014).

Moreover, the implementation of SFL in those sectors was usually partial, including in Denpasar City. Partial implementation of SFL means that smoking is prohibited in an enclosed building, however remain allows the sale and advertise cigarettes. This is paradoxical, when there is a ban but in the same time facilitates someone to smoke. 
Research shows that the implementation of a partial SFL in public places did not change a person's smoking status and smoking intensity, hence remain harms others (Zeng, et al., 2019). Many studies also confirmed that the partial implementation of SFL in both developed and developing countries often shows failure (Pinilla, et al., 2019). Thus, the implementation of the SFL in the hospitality sector considered to be revised to a total ban in order to improve the compliance and this compliance can be carried out in other sectors including in worship places.

Meanwhile, the other factor that significantly affected compliance in worship places was nicotine dependence which was measured using the fagestrom test and categorized into four levels i.e. low dependence, low to moderate dependence, moderate dependence, and high dependence (Heatherton et al.,1991). This study found that most of the respondents was categorized low dependence, however the analysis showed that it had significant indirect negative effect on compliance in worship places. Several literatures show that the relationship between the implementation of SFL and nicotine dependence can be assessed from two sides i.e. the implementation of SFL is associated with the decrease in nicotine dependence, the increase in smoking cessation and the decrease in smoking prevalence. On the other side, the presence of nicotine dependence as significant factor that hampered compliance to SFL. A longitudinal study showed that implementation of SFL in public places and workplaces has less effect on reducing nicotine dependence. Hence, to reduce nicotine dependence, smoking behavior in public places and the prevalence of smokers, it is important to implement a total ban with some prerequisites including the existence of other anti-smoking regulations or programs (Azagba \& Asbridge, 2013). More studies have shown that nicotine dependence inhibit compliance with SFL. The results of a systematic review both quantitatively and qualitatively regarding supporting and inhibiting factors with compliance with SFL clearly showed that nicotine dependence is an important barrier to the implementation of SFL (Zhou, et al., 2016). This review in accordance with the results of our study which also found nicotine dependence as a significant factor that inhibits compliance in worship places. It indicates that smoking cessation programs are urgently needed to help smokers deal with the nicotine dependence. Hence, the smoking cessation clinic that already established in several primary health care in Denpasar has to be more engaged.

Sociodemographic analysis showed that only the education level of the respondents significantly affected the compliance in worship places. The effect of education level on compliance with SFL is not only found in developing countries, but also in developed countries which have implemented SFL with many approaches (Aherrera et al., 2017). The education level of respondent in our study showed that most of them has passed high school and undergraduate degree. This shows that the higher the level of education of smokers, the higher compliance in worship places. Our result is consistent with study from China which found that the higher a person's education level, the lower the intention to smoke in public places. The higher education level of smokers was associated with better knowledge regarding the harm of second-hand smoke, and being more exposed to the recent anti-smoking regulation (Yang et al., 2016).

Social norm is one of the external factors assessed in this study which differentiated into descriptive norms and injunctive norms. Several studies have consistently found that social norm is one of the important factors that affect the increase of smoking behavior particularly among adolescents and a significant predictor of noncompliance with SFL. Thus, it suggested that study which assessing factors related to compliance with SFL should include social norms in their study (Page, et al., 2012). In our study, perceived descriptive norm of smoking in society had direct positive effect on compliance in worship places. It means, the more smokers perceive their family, friends, local leader, and community member avoid to smoke in worship places, the more compliance with SFL in worship places increased. Similarly, the perceived injunctive norms also had direct positive effect on compliance in worship places, which indicate the more smokers perceive their family and community expecting them not to smoke in worship places, the more compliance with SFL in worship places increased. These results are more consistent than study conducted in France which aimed to examine the relationship between smoking and several predictors including social norms. Their results show that social norms appear to be major predictors of smoking decisions and the number of cigarettes consumed. However, perceptions of injunctive norms such as perception of approval, occasional smoking and trial smoking have lower ranks in the model (França, et al., 2009). 
Meanwhile, other study found that actual injunctive norms are perceived to be more strongly associated with smoking intention than perceived injunctive norms (Zaleski \& Aloise-Young, 2013).

In our study, the influence of social norms on compliance in worship places also indicates that changes in social norms are the key to long-term compliance with SFL. Hence, the religiosity and a culturally sensitive approach have to be considered in promoting SFL in communities, particularly in rural areas. Changes in social norms involve changes in beliefs, attitudes or behaviors as result from interpersonal interactions or other forms of communication, such as mass media. Thus, social norms (unwritten rules regarding behavior) can be applied in the context of smoking behavior and can be used for further social change. The social norms of smoking remain important to study even under highly regulated climate..

\section{Limitations of the Study}

Compliance variable in this study was measured based on self-reported instruments that have been used in several studies effectively. However, recall bias from respondents during answering the question remains possible. This has been anticipated by modifying the answer by dividing the answers into five categories to minimize the bias. Moreover, the setting of this study only in worship places, while there are 6 others smoke-free areas. Hence, future studies should examine compliance factors in those areas to gain more factors that affected the compliance with smoke-free law.

\section{Conclusions and Recommendations}

It can be concluded that past behavior of smoking in other public places had the highest effect on smoking behavior in worship places followed by both of social norms factors. Hence, the improvement of smoke free implementation particularly in hospitality sector is essential through a routine and better socialization and supervision involving venue managers and other stakeholders including the community members. Future studies should gain more opportunities to revise the partial smoke-free policy in hospitality sector. Moreover, social norm factors also need more attention, thus a culture-sensitive strategy should be considered in the efforts of improving compliance particularly in worship places partly due to the high social acceptability and entrenched social norms around smoking. Hence, future studies could examine the effect of a cultural-sensitive approach to increase compliance in worship places.

\section{Acknowledgment}

The authors sincerely thank Center for NCDs, Tobacco Control and Lung Health, Universitas Udayana (Udayana Central) for the support throughout the study, to all respondents who kindly consented to participate in this study and to all enumerators for their valuable contribution to the study. We also thank the reviewers for their thoughtful review of our paper. The study was funded by the Ministry of Technology, Research and Higher Education of Indonesia. KS received an Indonesian National Postgraduate Education Scholarships (BPPDN) for his PhD.

\section{References}

Aherrera, A., Çarkoğlu, A., Hayran, M., Ergör, G., Ergüder, T., Kaplan, B., ... Navas-Acien, A. (2017). Factors that influence attitude and enforcement of the smoke-free law in Turkey: A survey of hospitality venue owners and employees. Tobacco Control, 26(5), 540-547. https://doi.org/10.1136/tobaccocontrol-2016-053088

Azagba, S., \& Asbridge, M. (2013). The association between smoking bans and nicotine dependence: A longitudinal analysis of current smokers in Canada. Addictive Behaviors, 38(12), 2817-2820. https://doi.org/10.1016/j.addbeh.2013.08.006 
Byron, M. J., Cohen, J. E., Frattaroli, S., Gittelsohn, J., Drope, J. M., \& Jernigan, D. H. (2019). Implementing smoke-free policies in low- And middle-income countries: A brief review and research agenda. Tobacco Induced Diseases, 17(August), 1-10. https://doi.org/10.18332/tid/110007

Byron, M. J., Cohen, J. E., Gittelsohn, J., Frattaroli, S., Nuryunawati, R., \& Jernigan, D. H. (2015). Influence of religious organisations' statements on compliance with a smoke-free law in Bogor, Indonesia: A qualitative study. BMJ Open, 5(12), 1-7. https://doi.org/10.1136/bmjopen-2015008111

Denpasar, P. K. (2018). Penduduk Kota Denpasar Per Kecamatan Tahun 2018. Retrieved from https://www.denpasarkota.go.id/new/public/ckfinder/userfiles/files/DATA TH 2018.pdf

Devhy, N. L. P., Astuti, P. A. S., \& Duarsa, D. P. (2014). Pengaruh Faktor Pengelola terhadap Kepatuhan Pelaksanaan Peraturan Daerah tentang Kawasan Tanpa Rokok pada Hotel Berbintang di Kabupaten Badung. Public Health and Preventive Medicine Archive, 2(2), 158-164. https://doi.org/10.15562/phpma.v2i2.144

Heatherton, T. F., Kozlowski, L. T., Frecker, R. C., \& Fagerstrom, K. -O. (1991). The Fagerström Test for Nicotine Dependence: a revision of the Fagerstrom Tolerance Questionnaire. British Journal of Addiction, 86(9), 1119-1127. https://doi.org/10.1111/j.1360-0443.1991.tb01879.x

Kegler, M. C., Hua, X., Solomon, M., Wu, Y., Zheng, P. P., \& Eriksen, M. (2014). Factors associated with support for smoke-free policies among government workers in Six Chinese cities: A crosssectional study. BMC Public Health, 14(1), 1-8. https://doi.org/10.1186/1471-2458-14-1130

Kementerian Kesehatan Republik Indonesia. (2018). Hasil Riskesdas 2018. November 2018. https://doi.org/1 Desember 2013

Kennedy, R. D., Behm, I., Craig, L., Thompson, M. E., Fong, G. T., Guignard, R., \& Beck, F. (2012). Outdoor smoking behaviour and support for outdoor smoking restrictions before and after France's national smoking ban. European Journal of Public Health, 22(SUPPL. 1), 29-34. https://doi.org/10.1093/eurpub/ckr208

Lwanga, S., \& Lemeshow, S. (1997). Sample Size Determintation For Health Study: A Practical Manual. Geneva: WHO.

Page, R. M., Huong, N. T., Chi, H. K., \& Tien, T. Q. (2012). Social normative beliefs about smoking among Vietnamese adolescents. Asia-Pacific Journal of Public Health, 24(1), 68-81. https://doi.org/10.1177/1010539510370993

Pemerintah Kota Denpasar. Perda Kota Denpasar No.7 Tahun 2013 tentang Kawasan Tanpa Rokok (2013). Denpasar. Retrieved from https://peraturan.bpk.go.id/Home/Details/20257/perda-kotadenpasar-no-7-tahun-2013

Pemerintah Provinsi Bali. Peraturan Daerah Provinsi Bali No. 10 Tahun 2011 Tentang Kawasan Tanpa Rokok (KTR) (2011). Retrieved from https://peraturan.bpk.go.id/Home/Details/22411/perdaprov-bali-no-10-tahun-2011

Pierce, J. P., Choi, W. S., Gilpin, E. A., Farkas, A. J., \& Merritt, R. K. (1996). Validation of susceptibility as a predictor of which adolescents take up smoking in the United States. Health Psychology: Official Journal of the Division of Health Psychology, American Psychological Association, 15(5), 355-361. Retrieved from http://www.ncbi.nlm.nih.gov/pubmed/8891714

Pinilla, J., López-Valcárcel, B. G., \& Negrín, M. A. (2019). Impact of the Spanish smoke-free laws on cigarette sales, 2000-2015: partial bans on smoking in public places failed and only a total tobacco ban worked. Health Economics, Policy and Law, 14(4), 536-552. https://doi.org/10.1017/S1744133118000270

Reis, M. F., Namorado, S., Aguiar, P., Precioso, J., Nunes, B., Veloso, L., ... Miguel, J. P. (2014). Patterns of adherence to and compliance with the Portuguese smoke-free law in the leisurehospitality sector. PLoS ONE, 9(7), 1-9. https://doi.org/10.1371/journal.pone.0102421

Rimal, R. N., \& Real, K. (2005). How behaviors are influenced by perceived norms a test of the theory of normative social behavior. Communication Research, 32(3), 389-414. https://doi.org/10.1177/0093650205275385 
Riou França, L., Dautzenberg, B., Falissard, B., \& Reynaud, M. (2009). Are social norms associated with smoking in French university students? A survey report on smoking correlates. Substance Abuse: Treatment, Prevention, and Policy, 4, 1-14. https://doi.org/10.1186/1747-597X-4-4

Sandra E. Echeverría, Daniel A. Gundersen, Michelle T.B. Manderski, and C. D. D. (2013). Social norms and its correlates as a pathway to smoking among young Latino adults. Soc Sci Med, 6(8), 187-195. https://doi.org/10.1021/nn300902w.Release

Suarjana, K., Putra, A. E., Astuti, P. A. S., Mulyawan, K. H., \& Chalidyanto, D. (2018). Compliance with smoke-free legislation and associated factors: A serial survey in Bali, Indonesia. Indian Journal of Public Health Research and Development, 9(11), 1840-1845. https://doi.org/10.5958/0976-5506.2018.01714.X

Tadesse, T., \& Zawdie, B. (2019). Non-compliance and associated factors against smoke-free legislation among health care staffs in governmental hospitals in Addis Ababa, Ethiopia: An observational cross-sectional study. BMC Public Health, 19(1), 1-11. https://doi.org/10.1186/s12889-019-6407-z

Yang, T., Jiang, S., Barnett, R., Oliffe, J. L., Wu, D., Yang, X., ... Cottrell, R. R. (2016). Who smokes in smoke-free public places in China? Findings from a 21 city survey. Health Education Research, 31(1), 36-47. https://doi.org/10.1093/her/cyv054

Zaleski, A. C., \& Aloise-Young, P. A. (2013). Using peer injunctive norms to predict early adolescent cigarette smoking intentions. Journal of Applied Social Psychology, 43(SUPPL.1), 1-14. https://doi.org/10.1111/jasp.12080

Zeng, S., Noguchi, H., \& Shimokawa, S. (2019). Partial smoking ban and secondhand smoke exposure in Japan. International Journal of Environmental Research and Public Health, 16(15). https://doi.org/10.3390/ijerph16152804

Zhou, L., Niu, L., Jiang, H., Jiang, C., \& Xiao, S. (2016). Facilitators and barriers of smokers' compliance with smoking bans in public places: A systematic review of quantitative and qualitative literature. International Journal of Environmental Research and Public Health, 13(12). https://doi.org/10.3390/ijerph13121228. 